\title{
Morphological, anatomical and antibacterial characteristics of Persicaria maculosa Gray plants growing in Lang Sen Wetland Reserve, Long An province, Vietnam
}

\author{
Phan Thi Kieu Mong ${ }^{1}$, Huynh Nguyen Van Anh ${ }^{2}$, Pham Van Ngot ${ }^{1}$ and Dang Thi Ngoc Thanh $2, *$ \\ ${ }^{1}$ Faculty of Biology, HCMC University of Education, 280 An Duong Vuong Street, Ward 4, District 5, Ho Chi Minh City. \\ ${ }^{2}$ Faculty of Natural Science Pedagogy, Sai Gon University, 273 An Duong Vuong Street, Ward 3, District 5, Ho Chi Minh \\ City, Vietnam.
}

GSC Biological and Pharmaceutical Sciences, 2021, 17(03), 107-118

Publication history: Received on 11 November 2021; revised on 13 December 2021; accepted on 15 December 2021

Article DOI: https://doi.org/10.30574/gscbps.2021.17.3.0356

\begin{abstract}
This study aimed to understand the adaptation characteristics of species Persicaria maculosa to living conditions and to add data on them as folk medicinal plants of Vietnam. Research methods included analysis of external morphological characteristics and microscopic structure of stems, leaves and roots. The antibacterial activities of ethanol plant extracts on four bacterial strains were also conducted through agar well diffusion method. The results showed that the plants had formed morphological and anatomical features to adapt to waterlogging and shade conditions. The leaf extracts from the concentrations of 600 to $1,000 \mathrm{mg} / \mathrm{L}$ had bacteriostatic activities against all four experimental strains with the bacterial inhibition zones from 2.39 to $10.91 \mathrm{~mm}$, in which inhibition of Bacillus cereus was the best.
\end{abstract}

Keywords: Bacterial inhibition zone; Lang Sen Wetland Reserve; Morpho-anatomical characteristics; Persicaria maculosa Gray; Plant extracts

\section{Introduction}

Persicaria maculosa Gray (syn. Polygonum persicaria L.), commonly known as lady's thumb, spotted lady's thumb, or redshank, was an annual weedy species in the buckwheat family, Polygonaceae. Plants often grew in moist areas of landfills, grasslands, riverbanks, irrigation ditches, and disturbed sites including croplands and gardens, but they also tolerated dry periods. Persicaria maculosa was thought to be native to Europe, or Eurasian, it was also stated as a native of China. However, the Eastern limits to its native range appeared to be uncertain [1]. This species was present on every continent and was particularly common in the Eastern regions of North America where it had been declared a noxious weed in parts of Canada and the United States [1]. In Vietnam, Persicaria maculosa was distributed in moist soils from the North to the South. Information about this species in Vietnam was mainly in the literature on folk medicine. The aerial parts or roots were harvested when the plant was growing well. They were used fresh or dried in folk remedies to treat diseases such as arthritis, diarrhea, jaundice, scurvy, cough, or applied topically due to their antiseptic properties [2-4].

Meanwhile, evidence of natural hybridization between P. persicaria and other species such as P. lapathifolium suggested the possibility of wide variation in the morphology of this species. Plasticity in traits of P. persicaria was also reported [1]. Even the suitable climatic conditions for the reproduction of this plant in countries with cold winters were different from those in a tropical country like Vietnam. In the world, studies on the anatomy, anti-proliferative and anti-cancer, and bacterial resistance of this species was published [5-7]. The medicinal properties of P. persicaria was also mentioned in the Russian Pharmacopoeia [8]. In Vietnam, research by Le Pha [9] showed the diversity of plants in Lang Sen Wetland Reserve, Long An province, including the genus Persicaria Mill. On that basis, the study on morpho-anatomical

\footnotetext{
${ }^{*}$ Corresponding author: Dang Thi Ngoc Thanh

Faculty of Natural Science Pedagogy, Sai Gon University, 273 An Duong Vuong Street, Ward 3, District 5, Ho Chi Minh City, Vietnam. 
adaptations of Persicaria maculosa plants growing in Lang Sen Wetland Reserve and the antibacterial ability of the plant extract was conducted to supplement the data of Vietnamese folk medicine.

\section{Material and methods}

\subsection{Samples collection}

Lang Sen Wetland Reserve was one of key sites for wetland biodiversity conservation in the Mekong Delta, Vietnam. Administratively, Lang Sen Wetland Reserve belonged to Tan Hung district, Long An province, covering an area of 4.802 hectares. The coordinates were between $10^{\circ} 45^{\prime}$ and $11^{\circ} 50^{\prime}$ North latitude and from $105^{\circ} 45^{\prime}$ to $105^{\circ} 50^{\prime}$ East longitude [10]. Sampling location (star shape) was in Sub-zone 11 of Lang Sen Wetland Reserve where the coordinates were $10^{\circ} 46^{\prime} 19^{\prime \prime}$ North latitude and $105^{\circ} 42^{\prime} 19^{\prime \prime}$ East longitude (Figure 1). Determining the Persicaria maculosa species based on the description of the three documents $[2,3,9]$.

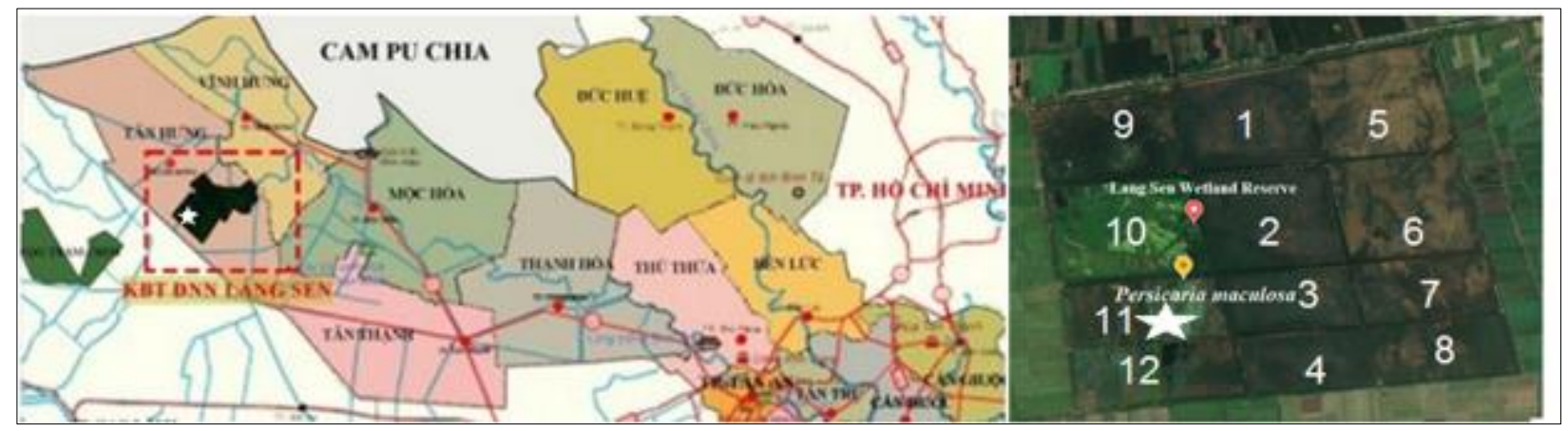

Figure 1 Sampling location (star shape) belonged to Sub-zone 11 of Lang Sen Wetland Reserve (within the rectangular dotted line) $[10,11]$

Soil, water and plant samples were collected in February 2021 and October 2021. Soil and water samples were taken as described in Vietnamese National Standards TCVN 7538-2: 2005 and TCVN 5994: 1995 respectively [12]. Fifteen plant samples were collected from 5 sites in each location, 3 plants per site, which were used for anatomical analysis. All samples were transferred separately into sterile plastic bags, sealed, labeled, refrigerated, and transported immediately to the laboratory. Fresh plant samples were stored in a refrigerator at $5^{\circ} \mathrm{C}$ for use in morphology study, and then preserved by immersion in ethanol $70 \% \mathrm{v} / \mathrm{v}$ for continued use in anatomy study.

\subsection{Analysis of some parameters of soil and water samples}

Soil samples were collected at positions from 0 to $30 \mathrm{~cm}$ from the surface layer, at least $2 \mathrm{~kg}$ were used to analyze some physic-chemical properties of the soil. These samples were sent to the Institute of Agricultural Science for Southern Vietnam for analysis of mechanical composition according to TCVN 8567:2010 and organic matter content according to TCVN 8941:2011 [12].

Parameters including $\mathrm{pH}$, salinity, drying coefficient were determined according to the method of Soils and Fertilizers Research Institute [13].

\subsection{Analyzing morphology and anatomical characteristics of plant}

Requirement of morphological-anatomical analysis on plant samples included characteristics medium-aged leaves, primary and secondary stems, primary and secondary roots, flowers and fruits collected at different growth stages.

Anatomical sections were prepared with a razor blade to thinly slice the leaves, stems and roots of the plant. Samples were double-stained according to the method of Tran Cong Khanh [14]. In the first step, the samples were soaked in chlorine bleach solution (Sodium Hypochlorite 0.5\% w/v) for $15 \mathrm{~min}$ to remove the cell endoplasm and was washed with distilled water. The samples were then soaked in 1\% acetic acid for about 5 min and rinsed with distilled water, followed by double staining with $4 \%$ carmine solution ( $10 \mathrm{~min}$ ) and $0.1 \%$ methylene blue solution (10 s). The size of the sample was determined by indirect measurement by comparing the size of the object to be measured with an eyepiece ruler fitted to the microscope. 
To study stomata, leaf samples were washed, drained and collodion coated on the upper and lower sides of the leaves. When the collodion dried, removed it and observed under the microscope with the eyepiece and micrometer. Epidermal images through collodion film at 100x magnification were recorded and the number of stomata was counted in a plot with an area of $1 \mathrm{~mm}^{2}$ [15].

\subsection{Investigation of the antibacterial ability of crude plant extract}

\subsubsection{Preparation of crude ethanol extract}

The leaf, stem and root samples of Persicaria maculosa plants were dried at $50^{\circ} \mathrm{C}$. Each type of sample was further ground and soaked in $96 \% \mathrm{v} / \mathrm{v}$ ethanol (1:10 ratio) at room temperature for 2 days. The extract was clarified through filter paper. The residue was further soaked in ethanol $96 \% \mathrm{v} / \mathrm{v}$ with the same ratio as above, repeated three times to ensure complete extraction [16].

The extract was evaporated from the solvent using a rotary evaporator (Rotary Evaporator RE301, Yamato Scientific) at $40^{\circ} \mathrm{C}-55^{\circ} \mathrm{C}$ until about $50 \mathrm{~mL}$ of extract was obtained, which was poured into a beaker and allowed to evaporate naturally until concentrated. When the solvent was completely evaporated, the crude extract was collected and stored in the dark and at $4^{\circ} \mathrm{C}$ for further experiments [16].

\subsubsection{Investigation of the antibacterial ability}

The crude extract mentioned above was re-dissolved in $70 \% \mathrm{v} / \mathrm{v}$ ethanol to give a stock solution concentration of 1,000 $\mathrm{mg} / \mathrm{mL}$. This stock solution was further diluted in $70 \% \mathrm{v} / \mathrm{v}$ ethanol to give a range of concentrations of $800 \mathrm{mg} / \mathrm{mL}, 600$ $\mathrm{mg} / \mathrm{mL}, 400 \mathrm{mg} / \mathrm{mL}$ and $200 \mathrm{mg} / \mathrm{mL}$. The negative control was a 70\% v/v ethanol solution corresponding to an extract content of $0 \mathrm{mg} / \mathrm{mL}$. The positive control was the antibiotic gentamicin $1 \mathrm{mg} / \mathrm{mL}$ (Gentamicin Sulfate - Gentamicin 80mg/2mL - DOPHARMA, Vietnam) and tetracycline $1 \mathrm{mg} / \mathrm{mL}$ (Tetracycline $500 \mathrm{mg}$ - Mekophar, Vietnam).

Antibacterial assay was performed by agar well diffusion method [17]. LB Agar medium was inoculated with bacterial suspension to give a concentration of $5 \times 10^{\wedge} 6 \mathrm{CFU} / \mathrm{mL}$ according to the McFarland Standards and poured into Petri dishes. Each $20 \mu \mathrm{l}$ of test compounds (plant extract/ ethanol 70/ antibiotic) was injected into each well. Plates were incubated at $37^{\circ} \mathrm{C}$ for 48 hours. The results were obtained by measuring the diameter of the zone of inhibition. The bacteria tested were 4 strains of Bacillus cereus, Bacillus subtilis, Staphylococcus aureus and Escherichia coli. Each treatment was repeated 3 times on 3 different Petri dishes. The antibacterial activity was calculated as the difference between the diameter of the inhibition zone (halo zone) and the diameter of the well (in $\mathrm{mm}$ ).

\subsection{Processing statistics}

Statistics methods were ANOVA one factor and LSD test at $\alpha=0.05$ by using IBM SPSS Statistics 20.0.

\section{Results and discussion}

\subsection{Some characteristics of soil and water where Persicaria maculosa plants grew}

Persicaria maculosa was distributed along the riverside of Sub-zone 11 of Lang Sen Wetland Reserve, growing in the shade mainly of Acacia auriculiformis. Mature plants developed on wetlands with many layers of decaying plant debris accumulating above the soil. Plant species living in the same habitat were recorded including Nymphaea pubescens, Salvinia cucullata, Azolla pinnata, Commelina longifolia, ect.

Soil texture analysis showed that the proportions of sand, silt and clay were $20 \%, 39 \%$ and $41 \%$, respectively, and the organic matter content was $9.92 \%$. Thus, the soil in the habitat of species Persicaria maculosa belonged to the clay with good water-holding and humus-holding properties. The measured EC (mS/cm) of the soil was 143, which proved that the soil was not saline. In terms of water characteristics (Table 1), the water was also not salty, had an almost neutral pH (6.67 - 6.87) and did not fluctuate greatly between the two seasons. In the rainy season, Persicaria maculosa plants still existed in flooded areas up to $91 \mathrm{~cm}$ deep. According to ISC [1], this species did not tolerate highly acidic soils and needed cold, moist conditions for germination. Seeds were dispersed through water, animals or environmental disturbances caused by cultivation. The environment in the Sub-zone 11 had suitable acidity, humidity and dispersal conditions as described above. 


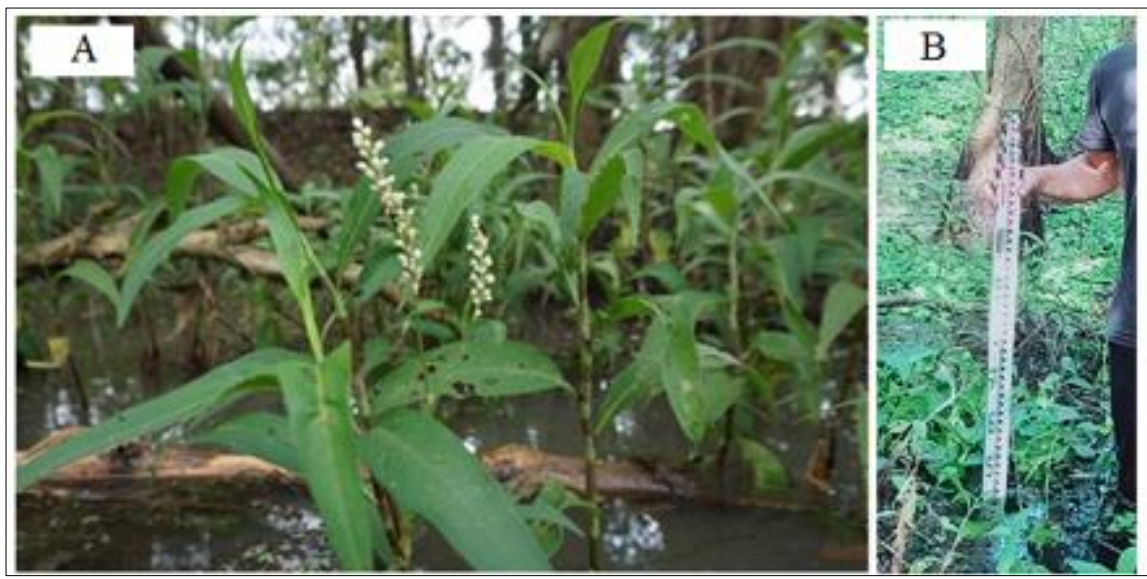

Figure 2 Habitat of species Persicaria maculosa (A); water table depth in the dry season (B)

Table 1 Some characteristics of water samples where Persicaria maculosa plants grew

\begin{tabular}{|l|c|c|}
\hline \multicolumn{1}{|c|}{ Criteria of water } & Dry season & Rainy season \\
\hline $\mathrm{pH}$ & $6.67 \pm 0.05$ & $6.87 \pm 0.10$ \\
\hline $\mathrm{EC}(\mu \mathrm{S} / \mathrm{cm})$ & $130.04 \pm 0.23$ & $129.82 \pm 0.83$ \\
\hline Water table depth $(\mathrm{cm})$ & $42.00 \pm 2.00$ & $91.70 \pm 3.80$ \\
\hline
\end{tabular}

\subsection{Morphological characteristics of Persicaria maculosa}

Persicaria maculosa was an herbaceous plant that grew as an annual, sometimes perennial. Stems were about 40 - 80 $\mathrm{cm}$ tall, erect or lying, with few branches (Figure $3 \mathrm{~A}$ ). The stem consisted of many internodes, each was $5-10 \mathrm{~cm} \mathrm{long}$. The young internodes were reddish in color, so it looked like light brown (Figure $3 \mathrm{E}$ ). The two ends of the internode were slightly enlarged, from the base of each internode sometimes grew many roots in the wrong place (Figure 3 B). Enclosing the base of each internode and extending upward the middle of the internode was a ciliate ochrea, a structure commonly found in the family Polygonaceae, which was rather long and hairy at the mouthparts (Figure 3 E, F). The leaves were alternately arranged and almost stalk less. Each leaf was about $10-15 \mathrm{~cm}$ long, lanceolate, entire margin, dark green on the adaxial side and slightly white on the abaxial side (Figure $3 \mathrm{C}, \mathrm{D}$ ).

In terms of reproductive organs, the inflorescence was a dense spike, $15-30 \mathrm{~cm}$ long, growing in leaf axils and apex. The tiny flowers were white, densely arranged on a peduncle (Figure $4 \mathrm{~A}, \mathrm{~B}$ ). The perianth of each flower consisted of five pieces of rhombic petals, fused near the base. Type of aestivation of corolla was twisted (Figure 4 C-F). There were 7 stamens attached on the corolla tube. The filament divided the anther into 2 equal parts (Figure 4 C). The pistil and the ovary made up of two fused carpels was located above the base of the petals. The style came out of the corolla and has 2 - 3 stigmas (Figure 4 G, H). The fruit was a shiny black, three-edged achene (Figure 4 I). This plant flowered from July to September in the temperate zone of the Northern Hemisphere, but in the South of Vietnam it flowered from March to November. Flowers bloomed in the morning, closed in the evening and continued to bloom the next day.

This study found some differences with the description of some documents. The description of Vo Van Chi [2] showed a brown spot commonly present on the upper surface of the leaves, consistent with the common English name "spotted lady's thumb" but neither in this study nor in description of some documents $[3,4]$. Regarding the appearance of dark burgundy spots on the leaves or stems (of Persicaria hydropiperoides), Verloove [18] suggested that was a typical characteristic of sun-exposed plants or parts of plants. This could be an explanation for leaf spotting or not in Persicaria species, including P. maculosa. The observed number of stamens of 7 also differed from the commonly described 6 and this required further investigation. Besides, some morphological changed to adapt to the environment were also observed. The roots grew from the base of the stem to help the plant fixed well to the ground or floated on the water. The old stem was sturdy with a root system that grew deep into the soil. The plant developed branches in a horizontal plane and rose above the water to expand the growth area. Due to being located under the shade of Acacia auriculiformis plants, most of the observed plants had horizontal spreading leaves with slightly downward leaf apex combined with elongated internodes to increase light absorption and photosynthesis. 


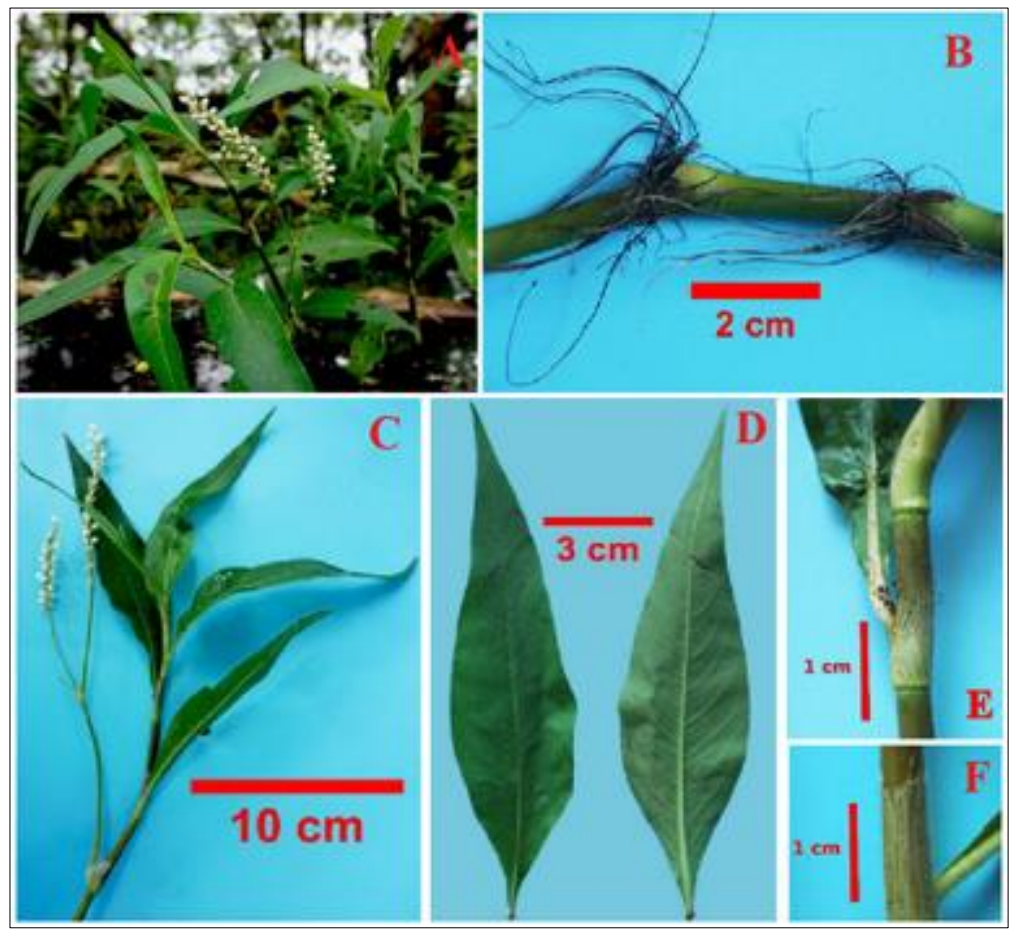

Figure 3 Morphology of vegetative organs of Persicaria maculosa
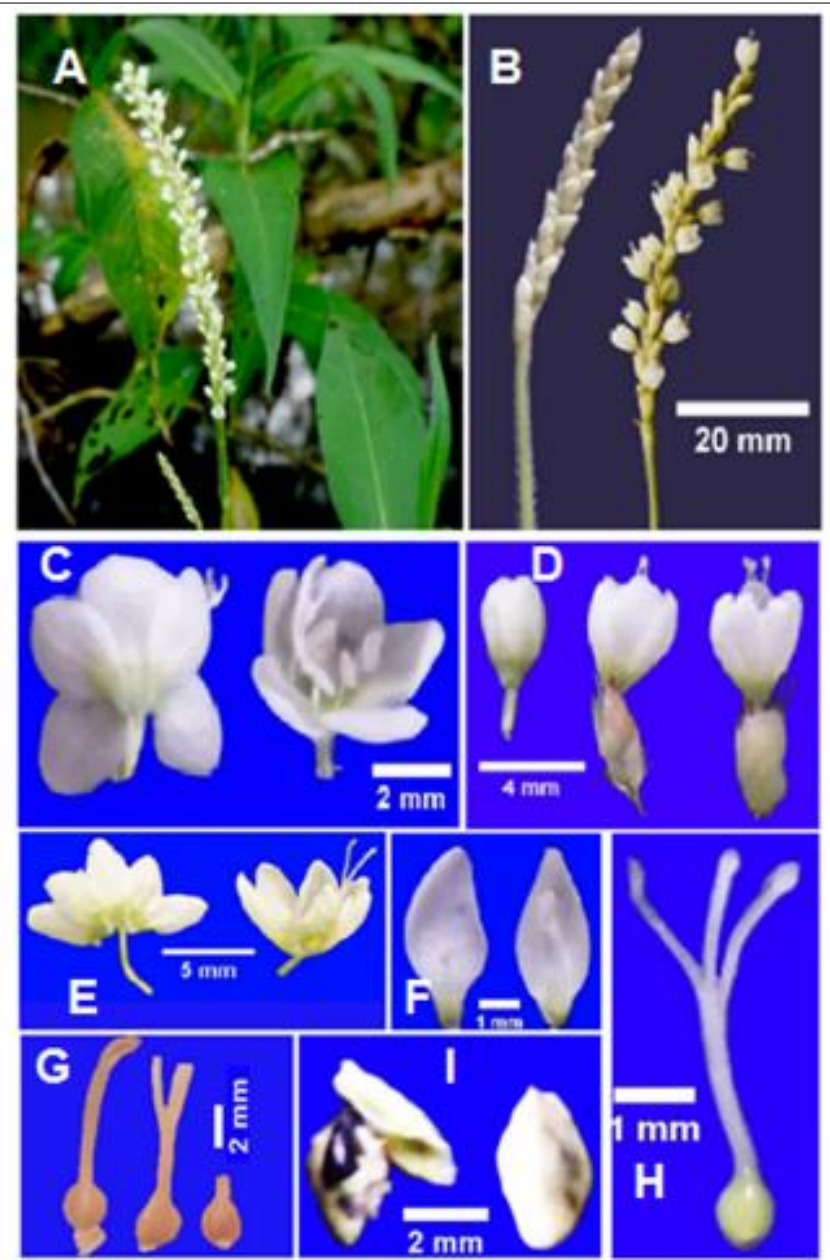

Figure 4 Morphology of reproductive organs of Persicaria maculosa 


\subsection{Anatomical characteristics of Persicaria maculosa}

\subsubsection{Anatomical characteristics of stems}

The transverse section of a primary stem was oval nearly round and had a pith cavity in the central (Figure 5 A). The results of anatomical features of Persicaria maculosa showed that the primary stem had an epidermis layer was observed in the outer region which consisted of small polygonal cells covered with cuticle. On the epidermis were scattered unicellular trichomes (Figure 5 B). Next to the inside of the epidermis was cortex collenchyma, which consisted of 4 - 7 layers of small polygonal cells. Cortex parenchyma were 3 - 6 layers of unequal globular cells, separated by large inter-cellular spaces and invaded by calcium oxalate crystals scattered in whole zone. The endodermis consisted of 1 - 3 layers of cells forming a closed loop, soon turning into hard tissue to increase the stem's rigidity. The thickness of the cortex accounted for approximately $13 \%$ of the radius of the primary stem (Table 2).

Table 2 Dimensions of components of primary stems (number of samples = number of iterations =15)

\begin{tabular}{|l|c|c|}
\hline Components & Thickness $(\boldsymbol{\mu m})$ & Percentage (\%) \\
\hline Epidermis & $10.67 \pm 1.44$ & 0.86 \\
\hline Cortex collenchyma & $52.29 \pm 6.96$ & 4.21 \\
\hline Cortex parenchyma & $57.55 \pm 11.39$ & 4.63 \\
\hline Endodermis & $22.26 \pm 3.67$ & 1.79 \\
\hline Primary phloem & $33.07 \pm 2.36$ & 2.66 \\
\hline Cambium & $9.26 \pm 2.64$ & 0.74 \\
\hline Primary xylem & $77.58 \pm 21.75$ & 6.24 \\
\hline Medullary parenchyma & $768.63 \pm 39.59$ & 61.82 \\
\hline Pith cavity & $212.12 \pm 17.22$ & 17.06 \\
\hline Total & $1243.44 \pm 38.81$ & 100 \\
\hline
\end{tabular}

The stele was the central part of the stem that made up most of the stem, included vascular tissue, medulla and a central hole (pith cavity) up to $424 \mu \mathrm{m}$ in diameter on average (Table 2). Primary vascular tissue consisted of 26 - 30 vascular bundles. Primary phloem was arranged on the outside and primary xylem on the inside and was separated by a vascular cambium that continuously arranged to form a closed round. There was also the presence of vascular bundles with only phloem on the outside but lacked of xylem on the inside. The medulla was composed of parenchymal cells with small intercellular spaces and progressively larger in size from the outside to the inside (Figure $5 \mathrm{C}$ ).

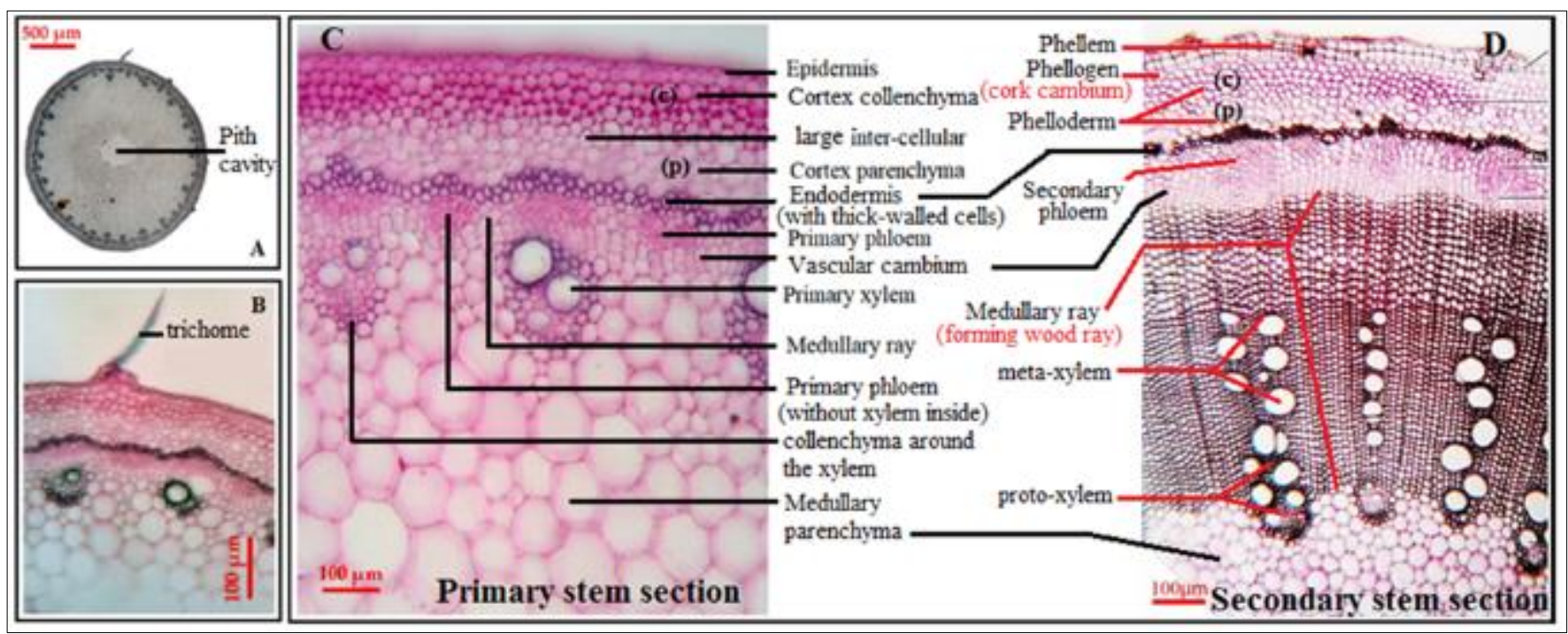

Figure 5 The structure of primary and secondary stems (A-D) of Persicaria maculosa;

(c) collenchyma; (p) parenchyma 
A cross section of the secondary stem (Figure 5 D) showed an underdeveloped cork layer (phellem). The cork cambium (phellogen) consisted of 2 - 3 layers of rectangular chlorenchyma cells, extending in a tangential direction. The phelloderm was similar to that seen in the primary cortex, consisting of 6 - 7 layers of angular collenchyma cells and 6 - 7 layers of spherical parenchyma cells with large intercellular spaces, some of which contained calcium oxalate crystals. The endodermis was unchanged, consisting of 2 - 3 layers of thick-walled cells arranged in a continuous ring. The vascular cambium grew markedly separating the outer secondary phloem and the inner secondary xylem. Within each bundle of xylem, the proto-xylem was still growing and was pushed inward relative to the meta-xylem. The medullary rays became wood rays creating a continuous ring woodened structure surrounding a ring of medullary parenchyma cells and a large central cavity up to about $55 \%$ of the stem diameter on average.

The study of P. maculosa growing in India by Manju and Vibhasa [5] also detected thickening of the endodermis cells as well as the development of a secondary woody ring that enhanced the stability of the stem. In contrast, for the cortex, there was a difference in the structure of $P$. maculosa growing in shaded areas in the valleys of India [5] and $P$. maculosa growing in riverside water in Lang Sen, Vietnam. The P. maculosa species that grew in India had a stem cortex consisting of 12 - 14 layers of parenchyma and 2 - 4 layers of oval-shaped collenchyma while in the present study it had a cortex consisting of 6 - 7 layers of parenchyma and 6 - 7 layers of collenchyma. The total number of cell layers of the stem cortex was similar, but the increase in the number of hard tissue layers was probably an adaptation of $P$. maculosa in aquatic environments, where the stem needed to be more stable under the influence of river currents.

\subsubsection{Anatomical characteristics of leaves}

The cross section of the leaf blade showed the egg-shaped (ovoid) midrib clearly on the abaxial side (Figure 6 A). The height of the symmetry axis of this ovoid was $1014.28 \mu \mathrm{m}$ on average. From outside to inside, the components of the midrib included the epidermis, collenchyma layers, parenchyma layers, vascular bundles and medullary parenchyma. The adaxial and abaxial epidermis were approximately $25.72 \mu \mathrm{m}$ thick and consisted of many closely spaced polygonal cells coated with cuticle on the outside and covered with trichomes with more abundance on the abaxial than on the adaxial. The adaxial consisted of 5 - 7 layers of angular collenchyma cells, while the abaxial had only 2 - 3 layers of such cells. The abaxial and bilateral parenchyma layers were more developed than the adaxial where there were only $1-2$ cell layers with large intercellular spaces. In terms of vascular tissue, there were 6 or 8 vascular bundles arranged in a ring just below the pericycle consisting of 2 - 4 sclerenchyma layers, of which the vascular bundle just below the adaxial surface was the largest. Each bundle had phloem cells on the outside and xylem cells on the inside. The medulla occupied about one-third of the longitudinal axis of the midrib, and was composed of many globular parenchyma cells (Figure 6 A-C).

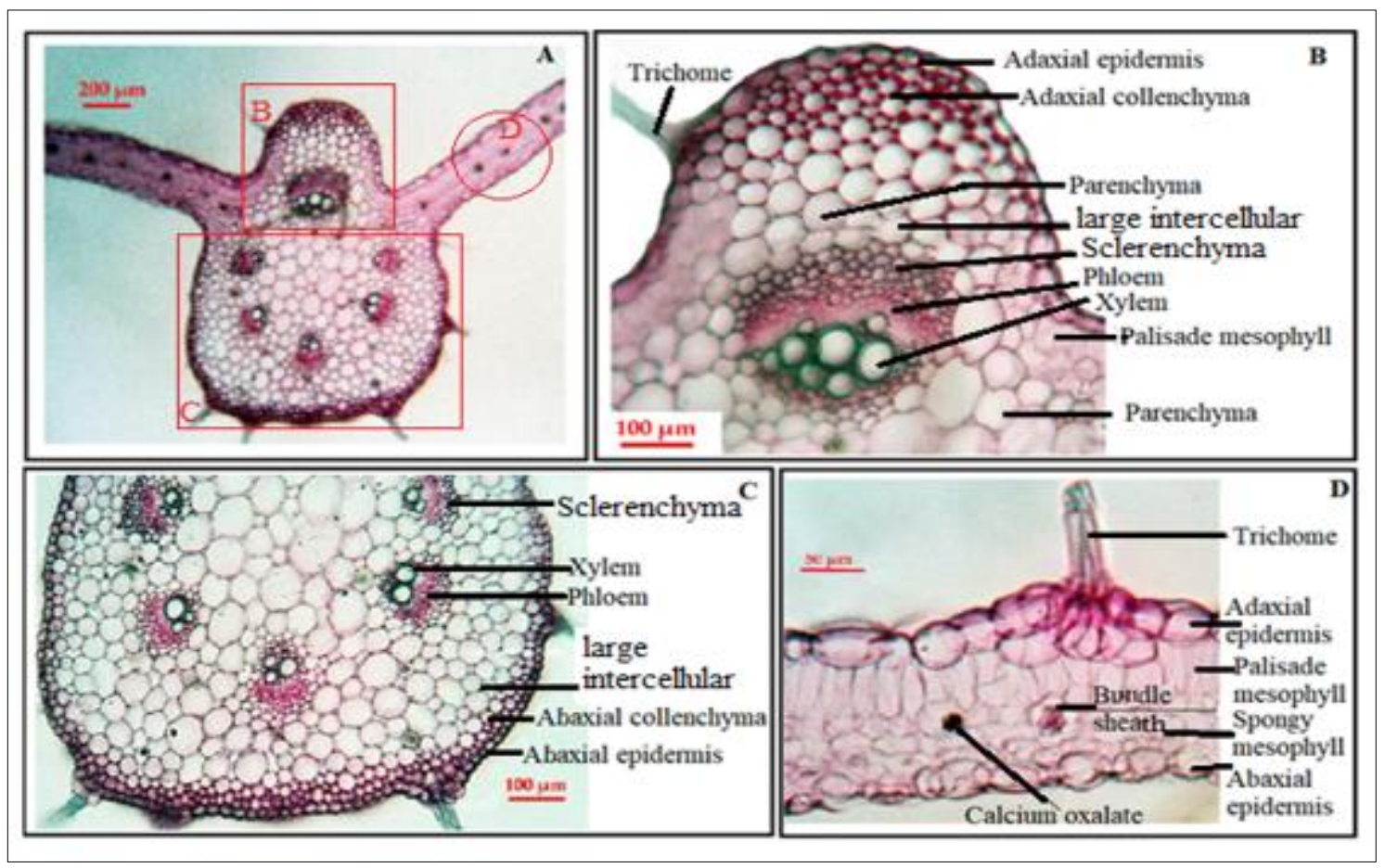

Figure 6 The anatomy of midrib and lamina of Persicaria maculosa 
Regarding the microscopic structure of the leaf blade (lamina), from adaxial down and from abaxial up to the central layer consisted of the epidermis, mesophyll and vascular bundles of veins. The adaxial and abaxial epidermis were approximately $25.72 \pm 3.04 \mu \mathrm{m}$ and $23.77 \pm 4.89 \mu \mathrm{m}$ thick, respectively, accounting for $13.7 \%$ and $12.7 \%$ of the lamina thickness. The adaxial palisade mesophyll consisting of 1 - 2 cell layers was $67.40 \pm 7.8 \mu \mathrm{m}$ thick, accounted for $35.9 \%$ while the abaxial spongy mesophyll consisting of $3-4$ cell layers was $67.40 \pm 7.8 \mu \mathrm{m}$ thick, accounted for $35.9 \%$. The vascular bundles of veins were very small with the phloem above and the xylem below and surrounded by cells of bundle sheaths (Figure 6 D).

The adaxial epidermis had a thicker cuticle layer and fewer stomata than the abaxial epidermis. Stomata was anisocytic (Figure 7) with the number on the adaxial and abaxial of $82.00 \pm 10.31$ and $188.80 \pm 9.78$, respectively. Trichomes of $P$. maculosa were uniseriate and non-glandular. They were abundantly on the midrib, both on the adaxial and abaxial sides. In addition, on the adaxial side of the lamina, some trichomes were also observed. Whereas the study of Yasmin et al. [19] on this species growing in Pakistan did not show the presence of trichomes on the lamina. The guard trichomes were adaptive organs that help reflected some of the radiant light from the sun, creating a microclimate that protected leaves from prolonged heat.
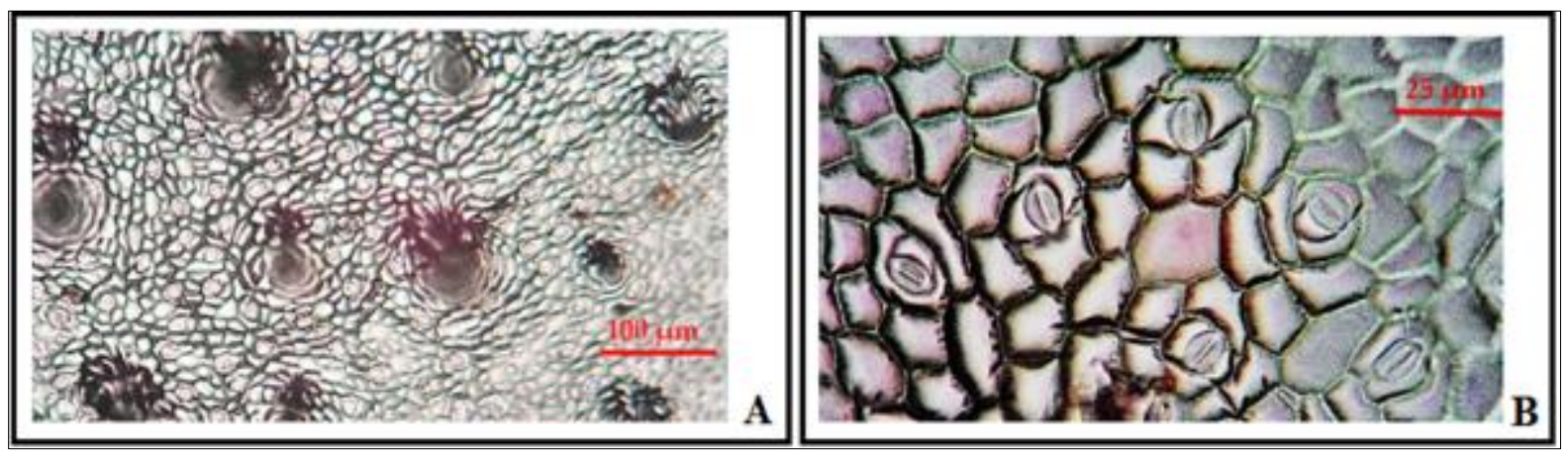

Figure 7 Distribution of trichome (black spots) (A) and pattern of stomata (B) on the adaxial epidermis of $P$. maculosa

\subsubsection{Anatomical characteristics of root}

The striking feature of the primary roots of P. maculosa was a quite small stele, accounting for only about 17 - $36 \%$ of the root diameter (Table 3). The cortex parenchyma consisted of sparsely arranged globular cells forming many very large intercellular spaces. This was one of the adaptations of roots to flooded conditions. The endodermis was a single layer of cells with indistinct Casparian strip. The pericycle consisted of a thin walled cell layer. Vascular tissue consisted of 4 - 5 bundles of phloem and xylem staggered and developed afferently. The medulla was composed of small globular parenchyma cells with small intercellular spaces (Figure $8 \mathrm{~A}, \mathrm{~B}$ ).

Table 3 Dimensions of components of primary roots (number of samples = number of iterations = 15)

\begin{tabular}{|l|c|c|}
\hline Components & Thickness $(\boldsymbol{\mu m})$ & Percentage (\%) \\
\hline Epidermis & $5.81 \pm 1.08$ & 2.18 \\
\hline Cortex parenchyma & $174.05 \pm 9.81$ & 65.26 \\
\hline Endodermis & $11.81 \pm 2.09$ & 4.43 \\
\hline Pericycle & $8.57 \pm 1.53$ & 3.21 \\
\hline Phloem & $21.05 \pm 2.71$ & 7.89 \\
\hline Xylem & $45.82 \pm 8.60$ & 17.18 \\
\hline Medullary parenchyma & $20.63 \pm 4.79$ & 7.73 \\
\hline Total & $266.70 \pm 9.59$ & 100 \\
\hline
\end{tabular}

In terms of secondary structure of Persicaria maculosa roots, a cork layer (phellem) was formed, which composed 2 - 3 layers of nearly rectangular cells arranged concentrically and radially around the outside, protecting the internal 
structures. Phellogen and phelloderm were difficult to distinguish, consisting of 2 - 3 layers of soft tissue cells. The hard and soft phloem of were alternate on the outside and were separated from the secondary xylem that forming a circular plate in the center by several layers of vascular cambium cells (Figure $8 \mathrm{C}$ ). The woodization of the medullary cells was similar to that of the secondary stem structure and the formation of a root-covering cork enhanced root stability, especially in waterlogged environments.

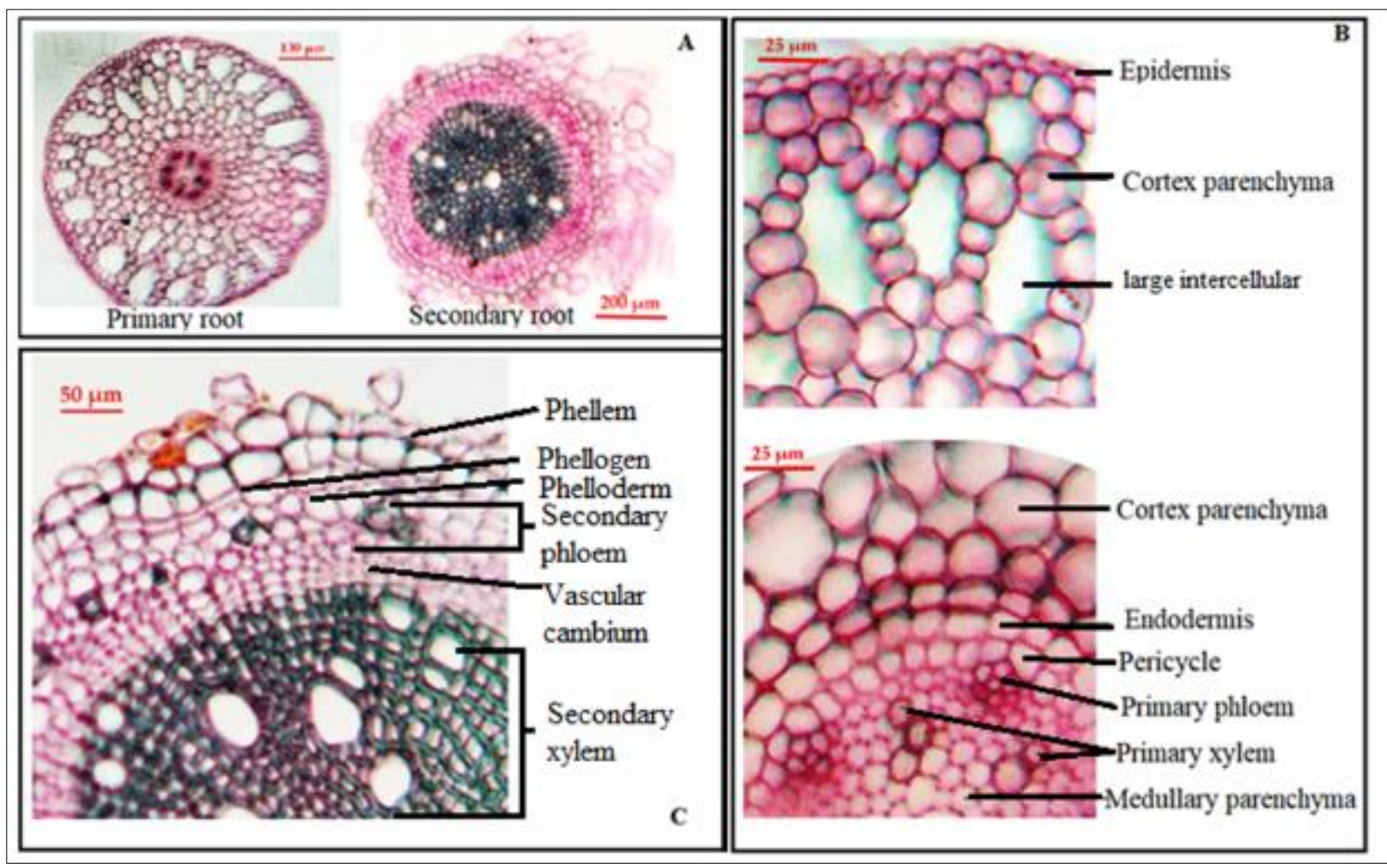

Figure 8 Anatomy of primary (B) and secondary (C) roots of Persicaria maculosa

\subsection{Antibacterial ability of the plant extract}

There were differences in antibacterial activity of stem, leaf and root extracts of Persicaria maculosa plants. The leaf extracts were effective against all four strains of bacteria (Table 4), while the stem extracts were effective only on Bacillus cereus and the root extracts were effective only on Bacillus subtilis.

Table 4 Antibacterial activities of the ethanol extracts of Persicaria maculosa

\begin{tabular}{|l|c|c|c|c|}
\hline \multirow{2}{*}{ Test samples } & \multicolumn{4}{|c|}{ Zone of bacterial inhibition (mm) } \\
\cline { 2 - 5 } & B. cereus & B. subtilis & S. aureus & E. coli \\
\hline E-1 & $10,91 \pm 0,43^{\mathrm{d}}$ & $6,93 \pm 1,17^{\mathrm{c}}$ & $6,11 \pm 1,45^{\mathrm{b}}$ & $9,16 \pm 1,01^{\mathrm{d}}$ \\
\hline E-2 & $10,03 \pm 0,32^{\mathrm{c}}$ & $4,09 \pm 0,90^{\mathrm{ab}}$ & $5,50 \pm 1,47^{\mathrm{b}}$ & $8,50 \pm 0,34^{\mathrm{cd}}$ \\
\hline E-3 & $9,65 \pm 0,13^{\mathrm{c}}$ & $7,17 \pm 0,11^{\mathrm{c}}$ & $2,39 \pm 0,04^{\mathrm{a}}$ & $7,61 \pm 0,12^{\mathrm{c}}$ \\
\hline E-4 & $6,91 \pm 0,66^{\mathrm{b}}$ & $4,65 \pm 0,12^{\mathrm{b}}$ & 0 & $6,26 \pm 0,04^{\mathrm{b}}$ \\
\hline E-5 & $4,71 \pm 0,36^{\mathrm{a}}$ & $3,19 \pm 0,13^{\mathrm{a}}$ & 0 & $2,93 \pm 0,04^{\mathrm{a}}$ \\
\hline E-0 (negative control) & 0 & 0 & 0 & 0 \\
\hline G-I (positive control) & $19,81 \pm 1,01^{\mathrm{e}}$ & $23,85 \pm 0,91^{\mathrm{d}}$ & $16,12 \pm 1,65^{\mathrm{c}}$ & $18,07 \pm 0,70^{\mathrm{e}}$ \\
\hline T-II (positive control) & $26,31 \pm 0,19^{\mathrm{f}}$ & 0 & $41,63 \pm 0,13^{\mathrm{d}}$ & 0 \\
\hline
\end{tabular}

The concentration of the leaf extract corresponding to the symbols: E-1: $1000 \mathrm{mg} / \mathrm{mL} ; \mathrm{E}-2: 800 \mathrm{mg} / \mathrm{mL} ; \mathrm{E}-3: 600 \mathrm{mg} / \mathrm{mL} ; \mathrm{E}-4: 400 \mathrm{mg} / \mathrm{mL}$ E-5: $200 \mathrm{mg} / \mathrm{mL}$; E-0: $0 \mathrm{mg} / \mathrm{mL}$ (negative control= ethanol 70\% v/v). G-I: Gentamicin $1 \mathrm{mg} / \mathrm{mL}$; T-II: Tetracycline $1 \mathrm{mg} / \mathrm{mL}$. Statistics by column. Data followed by the same letter were not statistically different $(\mathrm{a}<\mathrm{b}<\mathrm{c})$. 
On Bacillus cereus, the root extracts showed no antibacterial activity at all concentrations (Figure 9-1a). The stem extracts showed inhibitory effects on B. cereus at concentrations from $400-1,000 \mathrm{mg} / \mathrm{mL}$, corresponding to the inhibition zones with sizes from $3.74-7.45 \mathrm{~mm}$ (Data not shown in Table 4) (Figure 9-1b). Meanwhile, the leaf extracts had antibacterial activity at all concentrations with the inhibitory zone sizes gradually increasing from 4.71 to 10.91 $\mathrm{mm}$, corresponding to the concentration of 200 to $1000 \mathrm{mg} / \mathrm{mL}$ of the extracts (Figure 9-1c). These were also the inhibitory zones with the largest size obtained in the whole experiment.

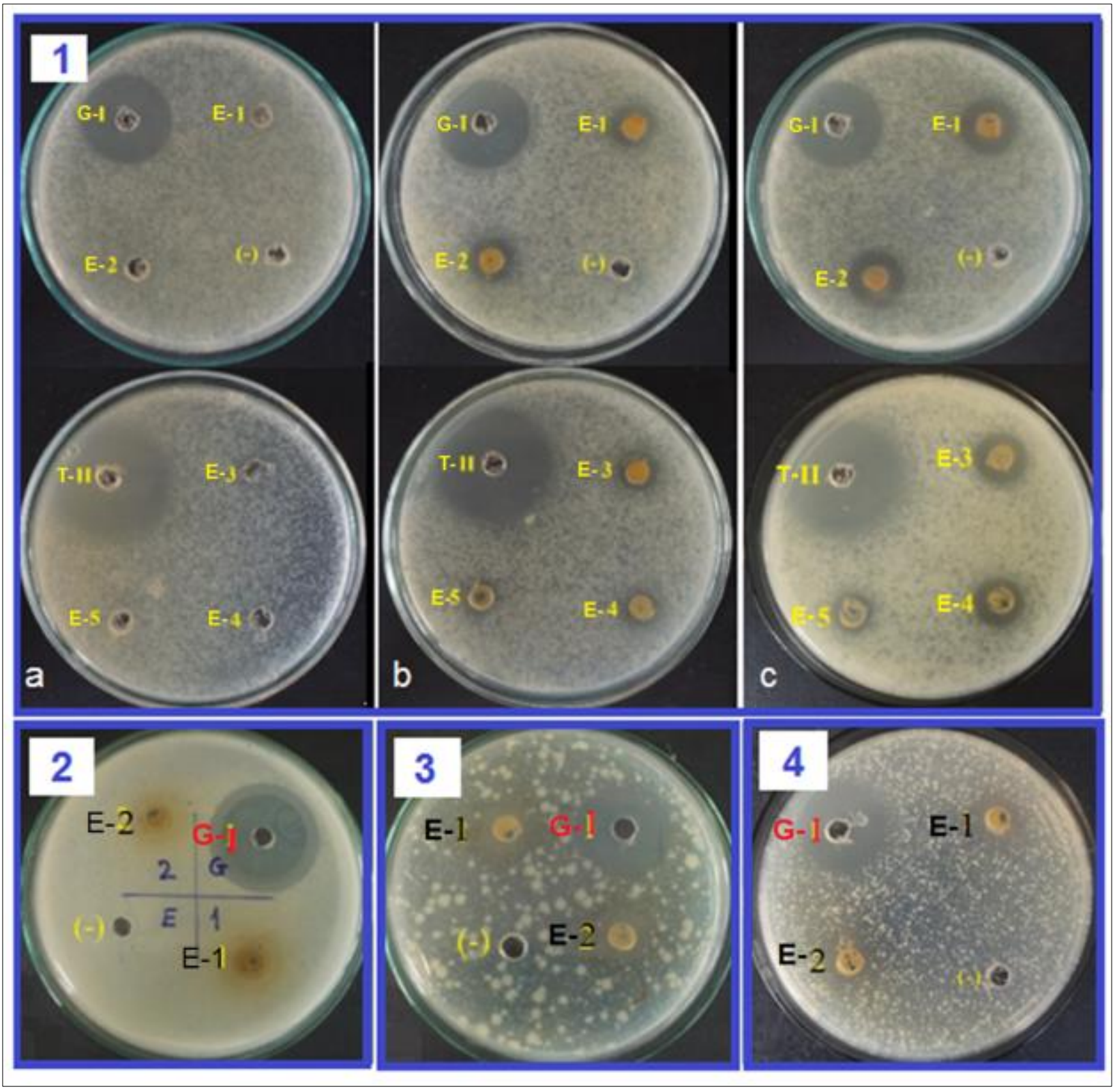

Figure 9 Bacterial inhibition zones of Persicaria maculosa plants extracts

(1): On B. cereus: (a) Root extract; (b) Stem extract; (c) Leaf extract; (2): Leaf extract on B. subtilis; (3) Leaf extract on E. coli; (4) Leaf extract on S. aureus; (E-1) 1,000 mg/mL; (E-2) $800 \mathrm{mg} / \mathrm{mL}$; (E-3) 600mg/mL; (E-4) $400 \mathrm{mg} / \mathrm{mL}$; (E-5) $200 \mathrm{mg} / \mathrm{mL}$; (-) negative control; (G-I) Gentamicin $1 \mathrm{mg} / \mathrm{mL}$; (T-II) Tetracycline $1 \mathrm{mg} / \mathrm{mL}$.

On Bacillus subtilis and Escherichia coli, antibacterial activities were only evident in leaf extracts at all concentrations with inhibition zones ranging from $3.19-6.93 \mathrm{~mm}$ and $2.93-9.16 \mathrm{~mm}$, respectively (Figure 9-1; 9-2). Meanwhile, on Staphylococcus aureus, the antibacterial activities of the leaf extracts were only shown at a concentration of $600-1,000$ $\mathrm{mg} / \mathrm{L}$ with the inhibition zones ranging from 2.39 to $6.11 \mathrm{~mm}$ (Figure 9-3). Especially on E. coli, the root extract showed antibacterial activity at a concentration of $600 \mathrm{mg} / \mathrm{L}$ with the size of the inhibition zone being quite small, $2.74 \pm 0.56$ $\mathrm{mm}$, but this was the only bacterial inhibition of root extracts that was found. 
The efficacy of P. maculosa extracts on different bacterial strains had been reported. If the ethanol extract in the experiment of Jovanović et al. [7] was effective against Pseudomonas aeruginosa at a concentration of $50 \mu \mathrm{g} / \mathrm{mL}$, at concentrations up to $5 \mathrm{mg} / \mathrm{mL}$ it was also ineffective against Escherichia coli and Enterococcus faecalis. Some documents in Vietnam recommend using the whole plant or the root part in the treatment of diseases [2,4], but through this study, it could be seen that the leaves were the part that proved effective in the antiseptic treatment of folk remedies.

\section{Conclusion}

Species Persicaria maculosa growing in Lang Sen Wetland Reserve showed the morphological and anatomical features adapted to the annual wetland environment that were different from the habitats in which individuals of the same species exist. The antibacterial activity of ethanolic extract from the leaves of Persicaria maculosa was effective against all 4 strains of bacteria tested including Bacillus cereus, Bacillus subtilis, Staphylococcus aureus and Escherichia coli.

\section{Compliance with ethical standards}

\section{Acknowledgments}

The authors would like to thank the support of Ho Chi Minh City University of Education and Saigon University.

\section{Disclosure of conflict of interest}

All authors declare no conflict of interest in relation to this article.

\section{References}

[1] The Invasive Species Compendium (ISC). Polygonum persicaria (redshank) [Internet]. Wallingford: CAB International; (C) Copyright 2021.

[2] Vo Van Chi. Vietnamese Medicinal Plants Dictionary, Volume 1. HCMC: Medical Publishing House. 2018.

[3] Pham Hoang Ho. Plants used as medicinal herbs in Vietnam. HCMC: Youth Publishing House. 2006.

[4] Thien Tri Thuc Oriental Medicine. Polygonum persicaria - Polyginum hydropiper [Internet]. Ha Noi: Nguyen Duc Thien Tri Thuc Company Limited; (C) Copyright 2021.

[5] Manju S, Vibhasa S. Stem anatomy of Persicaria Mill (Polygonaceae). Indian Journal of Plant Sciences (Online). 2013 October-December; 2(4): 155-161.

[6] Vasas A, Lajter I, Kúsz N, Forgó P, Jakab G, Fazakas C, Wilhelm I, Krizbai IA, Hohmann J. Flavonoid, stilbene and diarylheptanoid constituents of Persicaria maculosa Gray and cytotoxic activity of the isolated compounds. Fitoterapia. 2020 Sep; 145: 104610.

[7] Jovanović M, Morić I, Nikolić B, Pavić A, Svirčev E, Šenerović L, Mitić-Ćulafić D. Anti-Virulence Potential and In Vivo Toxicity of Persicaria maculosa and Bistorta officinalis Extracts. Molecules. 2020 Apr 15; 25(8): 18-11.

[8] Shikov AN, Pozharitskaya ON, Makarov VG, Wagner H, Verpoorte R, Heinrich M. Medicinal plants of the Russian Pharmacopoeia; their history and applications. J Ethnopharmacol. 2014 Jul 3; 154(3): 481-536.

[9] Le Pha. Research on plant diversity in Lang Sen Wetland Reserve, Long An Province [Master's Thesis]. Ho Chi Minh City: Ho Chi Minh City University of Education. 2018.

[10] Dang Van Son, Nguyen Linh Em, Le Pha, Pham Van Ngot, Nguyen Thi Mai Huong, Hoang Nghia Son. Diversity of flora in Lang Sen Wetland Reserve. Hanoi: Natural Science and Technology Publishing House. 2019.

[11] Google Earth. Location of tree samples in Lang Sen Wetland Reserve [Internet]. California: Google. (C) 2021 [cited 2021 Feb 1].

[12] Vietnam Standards and Quality Institute. Vietnam Look Standards [Internet]. Ha Noi: Vietnam Standards And Quality Institute; (C) 2016 [cited 2020 Nov 15].

[13] Soils and Fertilizers Research Institute. Handbook of soil, water, fertilizer, crop analysis. Hanoi: Agriculture Publishing House. 1998.

[14] Tran Cong Khanh. Practice of plant morphology and anatomy. Hanoi: University and Professional High School Publishing House. 1981. 
[15] Nguyen Nghia Thin. Methods of Plant Research, 2nd ed. Hanoi: Vietnam National University PublishingHouse. 2008.

[16] Nguyen Kim Phi Phung. Methods of Isolation of Organic Compounds. HCMC: Vietnam National University Publishing House. 2007.

[17] Balouiri M, Sadiki M, Ibnsouda SK. Methods for in vitro evaluating antimicrobial activity: A review. Journal of Pharmaceutical Analysis. 2016 Apr; 6(2): 71-79.

[18] Verloove F, Otto R, Janssens S, Kim S-T. A Cryptic Invader of the Genus Persicaria (Polygonaceae) in La Palma and Gran Canaria (Spain, Canary Islands). Diversity. 2021; 13(11): 551.

[19] Yasmin G, Khan M A, Shaheen N, Hayat MQ. Taxonomic significance of leaf epidermial anatomy of selected Persicaria Mill. Species of family Polygonacease from Pakistan. African Journal of Biotechnology. 2010; 9(25): 3759-3768. 